\title{
Feminizm amerykański trzeciej fali - zmiana i kontynuacja
}

\section{U źródel feminizmu}

$\mathbf{N}^{2}$ azwa feminizm pochodzi od łacińskiego słowa femina - kobieta, oznacza ruchy społeczne, ideologię i doktrynę skupione wokół problematyki równości prawnej, politycznej i społecznej kobiet z mężczyznami. W porównaniu do nazw innych ideologii czy doktryn, analiza etymologiczna nazwy - feminizm niewiele wnosi do pojęcia feminizmu. Pojawiła się dopiero w XX wieku oznaczając grupę problemów, zwanych wcześniej kwestią kobiecą, zajmujących się głównie równouprawnieniem i emancypacją kobiet $^{1}$.

U podstaw feminizmu leży przekonanie o niesprawiedliwym podporządkowaniu kobiet mężczyznom. O równość płci postulowali już w starożytności Hipparchia i inni filozofowie cynicy, a w IV w. p.n.e. Platon oznajmił, że kobiety podobnie jak mężczyźni mogą stać się władcami państwa lub pełnić w nich różne odpowiedzialne funkcje. Z kolei Sokrates nie popierał wyzwolenia kobiet, uważając że zrównana w prawach z mężczyzna kobieta staje się natychmiast jego zwierzchnikiem ${ }^{2}$.

W czasach nowożytnych postulat równości płci pojawił się w okresie Oświecenia i dwóch rewolucji: francuskiej i amerykańskiej. Pojawiające się we Francji i Stanach Zjednoczonych żądania równouprawnienia kobiet dotyczyły przede wszystkim praw wyborczych. Postulaty te nie zostały jednak spełnione, Amerykanka Abigaile Smith Adams, za swoje radykalne przekonania została wyśmiana przez członków Kongresu, z kolei Francuzka Olimpia de Gouges, autorka Deklaracji Praw Kobiet, została za swoje poglądy zgilotynowana ${ }^{3}$.

W historii feminizmu ważną postacią była również Angielka Mary Wollstonecratt, której dzieło Windykacja praw kobiet (ang. A Vindication of the Rights of Women) z 1792 r. uznaje się za pierwszy tekst teoretyczny feminizmu ${ }^{4}$.

\section{Feminizm pierwszej fali}

Początki feminizmu pierwszej fali (ang. First Wave Feminism), zwanej też starą falą datowane są na koniec XVIII w. W okresie tym w Ameryce nastąpiły wielkie zmiany. W toczącej się wojnie o niepodległość Stanów Zjednoczonych, zwanej także Rewolucją Amerykańską (1775-1783) zaangażowały się amerykańskie kobiety. Ich udział w walce o wyzwolenie kraju

\footnotetext{
${ }^{1}$ R. Tokarczyk, Współczesne doktryny polityczne, Zakamycze, Kraków 2000, s. 489.

2 Ibidem, s. 494.

${ }^{3}$ E. Majewska, Feminizm jako filozofia społeczna, Difin SA, Warszawa 2009, s. 23.

${ }^{4}$ R. Tokarczyk, Współczesne..., op. cit., s. 496.
} 
motywowany był chęcią zmiany sytuacji kobiet. To właśnie one zorganizowały w Bostonie w 1770 r. akcję protestacyjną nazwaną ,bostońskie picie herbaty”.

W okresie trwania wojny wyzwoleńczej wiele Amerykanek zaangażowało się w działalność na rzecz przyznania kobietom praw politycznych, wśród nich była również Abigaile Smith Adams, żona późniejszego prezydenta kraju ${ }^{5}$.

Po zakończeniu wojny sytuacja kobiet jednak nie zmieniła się, gdyż powszechnie przyjęto pogląd Thomasa Jeffersona, że prawdziwą demokrację można zbudować jeżeli wykluczy się kobiety ze wszystkich organizacji skupiających mężczyzn. Ostatecznie uchwalona w $1776 \mathrm{r}$. Deklaracja Niepodległości nie uznawała kobiet, ale także Indian i ludności czarnej za pełnoprawnych obywateli. Jej ogłoszenie spowodowało, iż podjęte przez kobiety działania zakończyły się niepowodzeniem. Należy jednak podkreślić, iż pragnienie uczestnictwa w życiu społecznym i politycznym wielu kobiet stało się inspiracją dla późniejszych pokoleń, i to nie tylko dla kobiet amerykańskich ${ }^{6}$.

Odradzający się w XIX w. ruch pierwszej fali feminizmu był odpowiedzią kobiet na brak możliwości samorealizacji siebie wynikający z napotykanych licznych barier prawnych i obyczajowych istniejących w amerykańskim społeczeństwie. Pierwszymi Amerykankami, które walczyły o równouprawnienie kobiet, popierając również zniesienie niewolnictwa były m.in.: Abigaile Adams, Sarah Grimie, Angelina Grimie, Frances Wright ${ }^{7}$.

Ważnym wydarzeniem w historii pierwszej fali feminizmu było zapoczątkowanie ruchu sufrażystek (łac. suffragium - prawo do głosowania), którego działalność rozpoczęła się wraz z Konwencją ${ }^{8}$ zorganizowaną przez Elizabeth Santon i Lucretia Coffine Mott w Seneca Falls w Nowym Yorku w 1848 r. Zgromadzone na spotkaniu kobiety: Elizabeth Cady Stanton, Susan B. Anthony, Lucretia Coffin Mott, dyskutowały o zniesieniu dyskryminacji ze względu na płeć. Przedmiotem ich zainteresowania były także prawa wyborcze, edukacja dziewczynek czy prawo do podjęcia pracy zawodowej utożsamianej z prawem do samodzielności. Podkreślano niesprawiedliwość związaną z podporządkowaniem kobiet mężczyznom, pozbawianiu ich decydowania o swoim życiu i posiadanym majątku. Głoszono również sprzeciw wobec braku możliwości podjęcia przez kobiety studiów uniwersyteckich czy prowadzenia działalności gospodarczej ${ }^{9}$. Działaczki feministyczne odważyły się zakwestionować powszechne przekonanie, iż jedynym przeznaczeniem kobiety jest małżeństwo. Elizabeth Cady Stanton i Susan B. Anthony przekonywały, że samorealizacja kobiet jest także ważna z punktu widzenia interesu społecznego, bowiem silna kobieta tworzy silną wspólnotę ${ }^{10}$.

Przed wojną secesyjną (1861-1865) przywódczynie ruchu kobiecego - Stanton, Anthony i Lucretia Coffin Mott uczestniczyły w konwencjach abolicjonistów, nawiązując liczne kontakty w celu zapewnienia kobietom amerykańskim i Afro-Amerykanom praw obywatelskich

\footnotetext{
${ }^{5}$ E. Majewska, Feminizm..., op. cit., s. 23.

${ }^{6}$ M. Ciechomska, Od matriarchatu do feminizmu, Wydawnictwo Brama, Poznań 1996, s. 106.

${ }^{7}$ M. Abel-Travis, Frances Wright: The Other Woman of Early American Feminism, „Women's Studies” 1993, t. 22 , s. 393 .

${ }^{8}$ Podczas obrad Konwencji w której uczestniczyło ok. 300 kobiet została uchwalona Deklaracja Opinii (podpisana przez 100 uczestniczek), parafrazująca amerykańską Deklarację Niepodległości uwzględniająca prawa kobiet. W Deklaracji Opinii sufrażystki krytykowały poddańczą sytuację kobiet i domagały się pełnego równouprawnienia amerykańskich kobiet.

9 S. G. McMillen, Seneca Falls and the Origins of the Women's Rights Movement, Oxford University Press, New York 2008, s. 3-6, 90-95.

${ }^{10}$ Ch. Hoff-Sommers, Feminism and Freedom, „, The American Spectator” July/August 2008, s. 58.
} 
(prawa do głosu i decydowania o swoim losie), czyli zrównanie ich w prawach z białymi mężczyznami ${ }^{11}$.

Po wojnie secesyjnej, która ostatecznie rozstrzygnęła kwestię niewolnictwa w USA okazało się jednak, że emancypacyjne dążenia sufrażystek i abolicjonistów nie podążają w tym samym kierunku. Wprowadzona w 1866 r. Trzynasta Poprawka do Konstytucji amerykańskiej zniosła niewolnictwo na obszarze całych Stanów Zjednoczonych. Z kolei Poprawka Czternasta ustanowiona w 1868 r. utorowała drogę do praw wyborczych afro-amerykańskiej ludności płci męskiej. Zmiany te spowodowały, że ruch kobiecy odseparował się od ruchu abolicyjnego i działał dalej niezależnie ${ }^{12}$.

W 1868 r. powstała organizacja kobieca National Woman Suffrage Association, na czele której stanęły Elizabeth Cady Stanton i Susan B. Anthony, żądając zrównania praw kobiet i mężczyzn we wszystkich sferach życia społecznego, politycznego i ekonomicznego. Kolejna organizacja American Woman Suffrage Association skupiająca sufrażystki została utworzona w 1869 r. przez Lucy Stone w celu osiągnięcia głównie pełnych praw obywatelskich dla kobiet. W 1890 r. organizacje te połączyły się i utworzyły National American Woman Suffrage Association, której pierwszą przewodniczącą została Elizabeth Cady Santon.

W drugiej połowie XIX w. nastąpiły zmiany w wielu obszarach życia amerykańskich kobiet. W latach 50. przeprowadzono reformę prawa małżeńskiego. Dzięki niej Amerykanki uniezależniły się od swoich męskich opiekunów. Z kolei w latach 60. i 70. przeprowadzono reformę systemu edukacji, dzięki której dziewczynki mogły rozpocząc naukę w szkołach i zdobyć wykształcenie. Reformy te zostały uznane za wielkie osiagnięcie feminizmu.

Na przełomie XIX i XX w. feminizm pierwszej fali był ruchem stawiającym sobie za cel przeprowadzenie zmian w systemach prawnych, zwłaszcza przyznania prawa wyborczego dla kobiet. W 1909 r. Amerykanki ogłosiły 8 marca dniem walki o równe prawa kobiet i mężczyzn, protestując tego dnia na nowojorskich ulicach, żądając praw wyborczych i prawa do uczestnictwa w życiu politycznym i społecznym ${ }^{13}$.

Aktywistki zaangażowane w równouprawnienie kobiet $\mathrm{z}$ coraz większą determinacją walczyły o swoje prawa. Organizowały demonstracje, pikiety, a nawet prowadziły strajki głodowe. Wśród nich wielką rolę odegrała walcząca przeciwko niesprawiedliwościom, uciskom i nadużyciom mężczyzn Suzan B. Anthony, która przyczyniła się do uchwalenia przez Kongres w 1920 r. Dziewiętnastej Poprawki do Konstytucji, co wiązało się z przyznaniem amerykańskim kobietom prawa wyborczego.

Dnia 26 sierpnia 1920 r. tysiące amerykańskich kobiet wyszły na ulice, by wyrazić swoją radość i świętować swój wielki sukces. Dziewiętnasta Poprawka do Konstytucji nazwana imieniem Susan B. Anthony, uwieńczyła trwające blisko sto lat zmagania kilku pokoleń amerykańskich kobiet $^{14}$.

Wiele problemów poruszanych w okresie pierwszej fali feminizmu dotyczyło głównie białych kobiet z klasy średniej. Oznaczało to, iż cele jakie posiadał ruch feministyczny były

${ }^{11}$ B. Epstein, The Successes and Failures of Feminism, „Journal of Women's History” Summer, 2002, s. 119; R. C. Dicker, A History of US Feminisms, Seal Press, Berkeley, CA 2008, s. 47-48.

12 A. Graff, Więcej niż kontekst-kwestia rasowa a feminizm w Stanach Zjednoczonych, w: Gender: konteksty, red. M. Radkiewicz, Kraków 2004, s. 53-69.

${ }^{13}$ Dzień 8 marca jako Międzynarodowy Dzień Kobiet, upamiętniający wystapienie kobiet amerykańskich przyjęto dopiero w 1914 r. Więcej na ten temat w: W. Malendowski, Polityczna emancypacja kobiet, w: Kobiety w polityce, wybrane problemy, red. W. Malendowski, Wydawnictwo Naukowe INPiD UAM, Poznań 1995, s. 11-12.

${ }^{14}$ S. M. Marilley, Woman Suffrage and the Origins of Liberal Feminism in the United States, 1820-1920, Harvard University Press, Cambridge, MA 1996, s. 281. 
związane z ich interesami. Inaczej wyglądała sytuacja kobiet należących do klasy robotniczej. W ich przypadku wykonywaną przez nie pracę zawodową nikt nie kwestionował, uważano nawet, że jest ona niezbędna. Podobnie zapatrywano się na sytuację czarnych kobiet. Działaczki ruchu feministycznego pierwszej fali często dystansowały się od nich i nie zajmowały się problemami innych kobiet niż białe.

\section{Feminizm drugiej fali}

Pierwsza fala ruchu feministycznego charakteryzowała się żądaniem równouprawnienia, utożsamiając je głównie z posiadaniem przez kobiety praw wyborczych. Ruch drugiej fali feminizmu ${ }^{15}$ zaczynający się w latach 60 . miał już inne cele, dążył do przebudzenia świadomości oraz przyspieszenia zmian statusu kobiet, walcząc o równość praw kobiet i mężczyzn nie tylko wyborczych, ale także pracowniczych. Usiłował ,wyzwolić” kobietę z tradycyjnego podporządkowania, zależności wywodzącej się z poglądu, że społeczna rola kobiety jest rolą usługową.

Aktywistki drugiej fali feminizmu były rozczarowane dotychczasowymi działaniami na rzecz równouprawnienia, skoncentrowanymi głównie na formalnych gwarancjach prawnych. Pomimo oczekiwań, zmiany prawne nie pociągnęły za sobą rzeczywistej równości płci. Feminizm drugiej fali był zaangażowany w przełamywanie stereotypów oraz dążył do zmiany społecznej, kulturowej czy obyczajowej, a nawet głosił potrzebę feminizacji świata.

Druga fala ruchu feministycznego znalazła się pod wpływem wzorców kulturowych. Domagano się gwarancji dla ,wyzwolenia” kobiet poprzez wprowadzenie wielu zmian legislacyjnych m.in.: prawo do antykoncepcji i aborcji oraz równość praw obywatelskich (bez specjalnego podkreślenia praw politycznych). Feministki drugiej fali walczyły o zmianę obyczajów i obalenie stereotypów płci przyjmując założenie o istnieniu w zbiorowości kobiet kolektywnej tożsamości płci.

W drugiej fali ruchu feministycznego na przełomie lat 60. i 70. dominował tzw. feminizm równości głoszący że, źródtem nierówności płci nie jest natura i naturalne ograniczenia, lecz patriarchalne ideologie, dyskryminacyjne praktyki ujawniajace sie już w procesie socjalizacji oraz wystęujace i powszechnie obowiqzujacych w spoteczeństwie stereotypach, dotyczacych podziatu ról na męskie i kobiece, podziału sfer aktywności między kobiety i mężczyzn. Nierówność płci jest zakorzeniona w kulturze. Jest wynikiem przyjętej organizacji społeczeństwa, a nie uwarunkowań biologicznych, eufemistycznie określanych jako naturalne. Z kolei dominujący w latach 80 . tzw. feminizm różnicy przyjmował istnienie różnic między kobietą a mężczyzną, sprzeciwiał się, aby dążenie kobiet do egalitaryzmu musiało prowadzić do zaniku kobiecej tożsamości płci i przejęcia przez nie męskich celów i kultywowanych wartości. Feminizm różnicy dążył zarówno do zakwestionowania patriarchatu jako porządku, który opiera się na nierówności płci, jak i feminizmu, który w imię równouprawnienia płci deprecjonuje kobiecość i kobiece wartości powodując, że kobieta traci tożsamość płci ${ }^{16}$.

W okresie drugiej fali feminizmu narodził się w wielu krajach Ruch Wyzwolenia Kobiet. Idea prawdziwej równości społecznej obu płci ogrywała główną rolę w ideologii Ruchu.

\footnotetext{
15 Termin feminizm drugiej fali (ang. Second Wave Feminism) został po raz pierwszy użyty przez Marsha Lear w $1968 \mathrm{r}$.

${ }^{16}$ E. Malinowska, Feminizm europejski, demokracja parytetowa a polski ruch kobiet, Wydawnictwo Uniwersytetu Łódzkiego, Łódź 2002, s. 66-67.
} 
W latach 60. w Stanach Zjednoczonych to właśnie Ruch Wyzwolenia Kobiet był najbardziej widocznym przykładem odrodzenia feminizmu i wzrostu aktywności wielu kobiet ${ }^{17}$. W amerykańskim Ruchu Wyzwolenia Kobiet ukształtowały się dwa główne nurty walczące o rzeczywiste uprawnienie kobiet. Pierwszy, nurt radykalny dążył do realizacji swoich celów postulując zmianę systemu kapitalistycznego. Nurt liberalny tworzyły głównie starsze feministki związane z prawica, reprezentujące różne organizacje kobiece, dążące do zmiany sytuacji kobiet $\mathrm{w}$ ramach istniejącego systemu społecznego. Dzięki prowadzonej przez nie działalności doszło do rozwoju ustawodawstwa dotyczącego równości kobiet w miejscu pracy. Drugi, nurt radykalny reprezentowały młodsze kobiety związane z lewica, których celem było radykalne przekształcenie społeczeństwa. Nie posiadał on jednak charakteru sformalizowanego. Nurt radykalny wskazywał, że największym źródłem opresji jest patriarchalna struktura społeczeństwa amerykańskiego, a warunkiem równouprawnienia kobiet jest jego radykalna zmiana.

Walka ruchu feministycznego o równouprawnienie płci była żądaniem, które opierało się na uznaniu kobiety za jednostkę dyskryminowana, gorszą w porównaniu z mężczyznami, a według określenia Simone de Beauvoir - za tzw. drugą płeć ${ }^{18}$.

W 1961 r. sytuacją amerykańskich kobiet zainteresował się prezydent John Kennedy, który powołał Komisję do Zbadania Statusu Kobiet (President's Commission on the Status of Women) w celu zbadania sytuacji kobiet na rynku pracy. W następnym roku ukazał się raport komisji Kennedy'ego ${ }^{19}$, z którego wynikało, iż w 1960 r. kobiety zatrudnione na pełnym etacie zarabiały $60 \%$ tego, co mężczyźni, a kobiety czarne - tylko $42 \%$. Komisja proponowała również m.in.: ustanowienie wspólnoty majątkowej w małżeństwach, zapewnienie szerokiej dostępności do ośrodków dziennej opieki nad dziećmi, wprowadzenie urlopów macierzyńskich dla kobiet, a także równej płacy za porównywalną pracę ${ }^{20}$.

W 1963 r. została opublikowana książka Tajemnica kobiecości Betty Friedan nazywana biblią feminizmu. Podjęta przez Friedan tematyka związana z tradycyjną rolą kobiety (gospodyni domowej i matki) w amerykańskim społeczeństwie patriarchalnym stała się inspiracją w podejmowanych przez przedstawicielki liberalnego feminizmu działaniach.

W 1966 r. aktywistka feministyczna Betty Friedan założyła National Organization for Women. Organizacja ta szybko przerodziła się w główną siłę prawicowego nurtu feminizmu.

Z powodu nierespektowania i lekceważącego podejścia sądów do ustanowionej poprawki o równości płci Friedan napisała: W 1966 r. istniała absolutna konieczność podjęcia ruchu na rzecz praw kobiet, napięcie osiagało alarmujacy stan zagrożenia podziemnym wybuchem, $i$ wystarczyło tylko kilka z nas, żeby iskra wznieciła płomień - a płomień rozszerzat się z siła nuklearnej reakcji łańcuchowej ${ }^{21}$. Tą, ,iskrą" o której pisała Friedan było powołanie do życia

${ }^{17}$ E. Gontarczyk, Kobiecość i męskość jako kategorie społeczno-kulturalne w studiach feministycznych, Wydawnictwo Eruditus, Poznań 1995, s. 17. W ramach działalności podejmowanej przez Ruch Wyzwolenia Kobiet został ustanowiony kierunek studiów: studia feministyczne (feminist studies), określane także studia kobiet (female studies) czy studia nad rolami płci (gender studies).

${ }^{18}$ E. Malinowska, Feminizm ...op. ci., s. 54. Simone de Beauvoir (1908-1986) francuska pisarka, żona Jeana Paula Sartre'a, autorka książki Druga płeć (1948) - poświęconej tematyce sytuacji kobiet.

${ }^{19}$ K. Ślęcza, Feminizm, ideologie i koncepcje społeczne współczesnego feminizmu, Wydawnictwo „Książnica”, s. 54; Oczekiwania kobiet wobec kobiet. Stereotypy i wzorce kobiecości w kulturze europejskiej i amerykańskiej, red. B. Płonka-Syroka, J. Radziszewska, A. Szlagowska, Wydawnictwo DiG, Warszawa 2007, s. 136.

${ }^{20}$ Ibidem; F. Davis, Moving the Mountain: The Woman's Movement in America since 1960, Simon \& Schuster, New York 1991, s. 17-18.

${ }^{21}$ B. Friedman, N.O.W. - How It Began, ,Women Speaking” April 1967, s. 4; R. Putnam-Tong, Myśl feministyczna, Wydawnictwo Naukowe PWN, Warszawa 2002, s. 36-37. 
National Organization for Women, pierwszej feministycznej organizacji jaka powstała w Stanach Zjednoczonych w XX w. Zrzeszone w tej organizacji feministki domagały się zaprzestania dyskryminacji płciowej we wszystkich sferach życia: społecznej, politycznej, ekonomicznej i prywatnej.

W 1967 r. światło dzienne ujrzał projekt ustawy o równych prawach kobiet (Bill of Rights for Women) zawierający popierane przez National Organization for Women następujące żądania: Po pierwsze, kongres Stanów Zjednoczonych bezzwłocznie powinien wprowadzić do Konstytucji poprawkę dotyczacq równych praw, aby wykazać że „Równość wobec prawa nie może być zanegowana czy ograniczona przez Stany Zjednoczone czy przez jakikolwiek Stan na podstawie różnicy płci”, a powyższe będzie natychmiast bezzwłocznie ratyfikowane przez poszczególne stany. Po drugie, należy zagwarantować wszystkim kobietom równe z mężczyznami szanse zatrudnienia wskazujac, że komisja ds. równego zatrudnienia wprowadza $w \dot{z} y$ cie przepisy dotyczqce zakazu dyskryminacji rasowej. Po trzecie, kobiety powinny być chronione przez prawo zapewniajace im powrót do pracy w jakiś czas po porodzie, przy czym nie będq tracić żadnego z przysługujacych im zasilków lub swojej wyższej pozycji w pracy oraz powinny dostawać zasiłek macierzyński jako formę świadczenia zabezpieczajacego i/lub świadczenia pracownicze. Po czwarte, powinno się przeprowadzić natychmiastowa rewizje zasad opodatkowania, aby umożliwić odpis podatkowy z wydatków na dom i opiekę nad dzieckiem dla pracujacych rodziców. Po piqte, należy ustanowić przepisy dotyczqce różnych ułatwień w sprawowaniu opieki nad dzieckiem na tych samych zasadach prawnych, na jakich funkcjonuja parki, biblioteki i szkoty publiczne, ułatwienia te powinny być dostosowane do wymagań dzieci od wieku przedszkolnego po okres dojrzewania i mogły być użytkowane jako zasoby komunalne przez wszystkich obywateli niezależnie od poziomu dochodów. Po szóste, prawo kobiet do uzyskania petnej edukacji na równi z mężczyznami powinno być zapewnione przez legislacje stanowq i federalnq, która wyeliminuje wszelka dyskryminację $i$ segregacje ptciowa, pisanq i niepisana, na wszystkich poziomach kształcenia właczajac college, szkoły wyższe i uniwersytety, pożyczki stypendia, członkostwo, federalne i stanowe programy szkoleniowe takie jak Job Cors. Po siódme, należy zapewnić ubogim kobietom szkolenia zawodowe, mieszkania i zasitki rodzinne na takich samych zasadach, jakie dotyczq mężczyzn, jednak bez uprzedzeń wtedy, gdy rodzic chce zostać w domu, by zajmować się swoimi dziećmi; należy dokonać rewizji ustawodawstwa dotyczqcego pomocy spotecznej i jej programów, które odmawiaja kobietom prawa do godności, prywatności i szacunku dla samej siebie. Po ósme, należy gwarantować kobietom prawo do zarzqdzania swoim życiem reprodukcyjnym przez usunięcie paragrafów karnych praw ograniczajacych dostęp do informacji, sposobów $i$ środków antykoncepcyjnych i przez zniesienie prawa karnego dotyczacego aborcji ${ }^{22}$.

Przyjęcie w tym samym roku, na pierwszej krajowej konferencji w Waszyngtonie projektu ustawy zawierającej postulaty National Organization for Woman było dla organizacji wielkim sukcesem.

W 1970 r. zostały opublikowane dwie książki o wielkim znaczeniu dla procesu zmian, jaki dokonywał się w okresie drugiej fali: Polityka płciowa (Sexual Politics) Kate Millett oraz Dialektyka ptci (The Dialectic of Sex: The Case for Feminist Revolution) Shulamith Firestone.

W swojej książce Millett starała się ukazać, że kobiety zostały poddane wewnętrznemu skolonializowaniu (interior colonization). Autorka nazywa patriarchat systemem wyzysku

\footnotetext{
22 NOW (National Organization for Woman) projekt ustawy w: Sisterhood is Powerful, red. R. Morgan, Random House, New York 1970, s. 513-514; R. Putnam-Tong, Myśl feministyczna..., op. cit., s. 37-38.
} 
kobiety, podkreśla, że rewolucja płciowa była trudna do przeprowadzenia, gdyż trudno było zmienić tradycyjny sposób myślenia amerykańskiego społeczeństwa. Proponuje alternatywę klasycznego modelu rodziny, uważając, że małżeństwo można zastąpić dobrowolnym stowarzyszeniem. Millett zauważa również, że ideologia panowania białego mężczyzny nad czarnym przestała być tematem wielkiej wagi, po czym krytykuje brak ochrony białej kobiety, co sprawia, że panowanie białych mężczyzn nad kobietami jest dla nich nadrzędne. Na koniec przestrzega, że „seksizm” może być bardziej zakorzeniony niż sam rasizm ${ }^{23}$.

Z kolei Shulamith Firestone, współzałożycielka organizacji radykalnych feministek o nazwie The Redstockings w swojej książce starała się udowodnić, że źródło dyskryminacji kobiet, które według autorki trzeba usunąć na drodze rewolucji feministycznej, tkwi w przypisanej kobiecie funkcji rodzenia i opiekowania się dziećmi. Firestone krytykuje ostro instytucję małżeństwa i model tradycyjnej rodziny. Uważa, że ,,póki trwa rodzina, póty trwa ustrój klas płciowych. Postuluje przeobrażenie, a nawet zniesienie rodziny, uznaje również swobodę seksualną dzieci podobnie do swobody dorosłych. Wiele liberalnych feministek żyjących najczęściej w związkach małżeńskich, ale również feministki radykalne, uznały że taka publiczna krytyka instytucji małżeństwa i rodziny może okazać się nieprzyjazna dla ruchu ${ }^{24}$.

W 1970 r. głośna i kontrowersyjna stała się również wypowiedź innej feministycznej pisarki Robin Morgan, która przyrównała instytucję małżeństwa do systemu niewolnictwa, uważając, że nierówność między kobietą a mężczyzną, będzie istnieć aż do czasu, kiedy nie zlikwiduje się małżeństwa ${ }^{25}$.

W latach 80. feminizm drugiej fali podjął problem egalitaryzmu opartego na wielopłaszczyznowym pojmowaniu ucisku, który jest wynikiem podziałów płciowych. W tym okresie poruszane są także problemy związane np. z aborcją czy homoseksualizmem. Betty Friedan w 1981 r. zdystansowała się do ruchu feministycznego, który wcześniej tworzyła uważając, że niedobrze się stało, iż ruch kobiet został oskarżony o działalność na rzecz rozpadu rodziny i małżeństwa ${ }^{26}$.

\section{Feminizm trzeciej fali}

Feminizm trzeciej fali (ang. Third Wave Feminism) nazywany jest też przez niektórych postfeminizmem ${ }^{27}$. Narodzenie trzeciej fali datowane na lata 90 . nie jest uznawane przez wszystkich badaczy. Część z nich uznaje jedynie dwie fale feminizmu. Ruch trzeciej fali krytykowano na początku za ograniczanie go do problemów głównie białych, heteroseksualnych kobiet z klasy średniej, które mogły w okresie drugiej fali walczyć m.in.: o prawo do antykoncepcji, aborcji czy rozwodów. Po czym feminizm trzeciej fali stał się reprezentantem wielu kultur, tożsamości etnicznych, religijnych, czy rasowych stając się ruchem heterogenicznym.

W 1992 r. Rebecca Walker, córka jednej z liderek czarnego feminizmu napisała Ja nie jestem feministkq doby postmodernizmu. Ja jestem trzecia fala. Artykuł Becoming the Third Wave (Stajac się trzeciafala) ukazał się na łamach sztandarowego magazynu feministek dru-

\footnotetext{
${ }^{23}$ K. Ślęcza, Feminizm, Ideologie..., op. cit., s. 131-140.

${ }^{24}$ Ibidem, s. 140-145.

${ }^{25}$ R. Morgan, Sisterhood Is Powerful, Random House, New York 1970, s. 537.

${ }^{26}$ B. Friedan, The Second Stage, Cambridge University Press, Cambridge 1998, s. 10.

${ }^{27}$ Część badaczy uważa jednak, że jest to błędne i mylące określenie, gdyż znacznie częściej postfeminizm nazywa się konserwatywną reakcję wobec feminizmu drugiej fali.
} 
giej fali „Ms.”. Walker w swoim manifeście rzuciła wyzwanie w stronę zdominowanej przez mężczyzn kulturze i mediom, które już kilka razy ogłosiły „śmierć feminizmu”. Głosząc swoistą deklarację niepodległości pokolenia młodych feministek wobec pokolenia swoich amerykańskich matek ${ }^{28}$ szuka swojej nowej feministycznej tożsamości.

Trzecia fala feminizmu podkreśla swoją niezależność i odrębność głosząc hasło - Nie jestem siostra mojej matki - jestem po prostu sobą. Feminizm trzeciej fali to feminizm otwarty na problemy wszystkich kobiet. Poruszane są w nim sprawy kobiet z wcześniejszych fal, ale również zagadnienia uznawane wcześniej za sferę tabu.

Termin feminizm trzeciej fali pojawił się na łamach czasopisma „Ms.”. W 2000 r. została wydana Manifesta: Young Women, Feminism and the Future napisana przez Jennifer Baumgardner i Amy Richards. W swoim feministycznym dziele uznanym za manifest trzeciej fali, autorki postawiły sobie za cel ożywienie działalności ruchu, głosząc potrzebę zajęcia się problemami współczesnych kobiet. Aktywistki trzeciej fali reprezentują grupy kobiet wcześniej wykluczone z udziału w ruchu. Jedna z czołowych przedstawicielek czarnego feminizmu, Bell Hooks, (właśc. Gloria Jean Watkins), autorka wielu książek, napisała słynne dzieło $\mathrm{Fe}$ minist Theory: From Margins to Center, w którym polemizuje z koncepcją feminizmu podkreślającą dążenie do równouprawnienia kobiet i mężczyzn. W Feminist Theory autorka zwracając uwagę na podziały klasowe w społeczeństwie i problem uprzedzeń rasowych, podkreśla, że sami mężczyźni nie są sobie równi. Oświadcza więc, że problem z którym zmaga się feminizm nie leży w nierówności płci, ale w męskiej dominacji związanej również z dominacją rasową i ekonomiczną. Dlatego też proponowana przez Bell Hooks wizja feminizmu trzeciej fali jako ruchu społecznego powinna skupić się na zniesienia ucisku ze względu na płeć, w którym to biorą udział kobiety, a także mężczyźni, walcząc razem z innymi ruchami przeciwko jakimkolwiek formom ucisku i dominacji. Czołowa przedstawicielka trzeciej fali feminizmu podkreśla również, że uznanie różnorodności ludzkich doświadczeń jest sprawą fundamentalną. Hooks proponuje również swoją definicję „siostrzeństwa”. Jej zdaniem nie istnieje wspólny interes wszystkich kobiet, dlatego więc według niej „siostrzeństwo” powinno oznaczać tworzenie wspólnego ruchu przez kobiety, które mają różne doświadczenia i interesy ${ }^{29}$.

Działalność Hooks na rzecz kobiet wskazywała, że dotychczas feminizm był ruchem reprezentowanym przez białe kobiety klasy średniej Zachodu, które uzurpowały sobie prawo do wypowiadania się w imieniu wszystkich kobiet, nie uwzględniając odmiennych stanowisk i problemu różnorodności. Wiele aktywistek trzeciej fali feminizmu uważało, że nie można walczyć o równouprawnienie kobiet nie uwzględniając emancypacji grup kobiet reprezentujących różną rasę, klasę społeczną, pochodzenie etniczne, kulturę czy religię. Powstające nowe nurty feminizmu (np. feminizm czarny czy latynoski) krytykowały dotychczasowy feminizm za głoszenie poglądu, że istnieje wspólna, niezmienna istota kobiecości.

Problemy klasowe i rasowe pomijane przez dwie pierwsze fale feminizmu, a podjęte przez aktywistki trzeciej fali wskazywały na istniejącą różnorodność przejawiającą się w wieloetnicznym, wieloreligijnym, wielokulturowym społeczeństwie amerykańskim.

Od lat 90. XX w. zauważa się, że zainteresowanie feminizmem coraz bardziej przesuwa się z problemów politycznych czy ekonomicznych na zagadnienia związane z kulturą czy psychologią w relacjach kobiet z mężczyznami. Powstały nowe czasopisma i prasa femini-

${ }^{28}$ A. Graff, Trzecia fala feminizmu, na: www.wysokieobcasy.pl/wysokie-obcasy/1,53581,2715339.htlm; J. Coleman, An Introduction to Feminism in the Postfeminist Age, „,Women’s Studies Journal” 2009, t. 23, nr 2.

${ }^{29}$ Więcej na ten temat: M. Baer, Ewolucja myśli feministycznej w antropologii kulturowej, w: Humanistyka i pleć, red. E. Pakszys, D. Sobczyńska, Wydawnictwo Naukowe UAM, Poznań 1997, s. 248-249. 
styczna, a także został ustanowiony specjalny kierunek studiów na zachodnich uczelniach tzw. studia kobiece (ang. Women's Studies).

Trzecia fala feminizmu jest również przedmiotem krytyki, głównie z powodu braku wspólnego celu i dlatego często jest postrzegana jako kontynuacja drugiej fali. Podczas gdy pierwsza fala przyniosła głównie prawo kobiet do głosowania, druga prawo równych szans kobiet-pracowników, a także zakończyła prawną dyskryminację płci, trzecia fala nie posiada określonej definicji. Pomimo to dla wielu młodych feministek poszukujących swojej społecznej tożsamości, refleksja nad problemem relacji płci i statusem kobiet i mężczyzn w amerykańskim społeczeństwie nadal pozostaje aktualnym problemem.

\section{Summary}

\section{American Feminism - the Third Wave. The Change and Continuation}

The history of American women fighting for equal rights dates back to the $18^{\text {th }}$ century, when in Boston, in 1770, they voiced the demand that the status of women be changed. Abigail Adams, Sarah Grimke, Angelina Grimke and Frances Wright are considered to have pioneered American feminism. An organized suffrage movement is assumed to have originated at the convention Elizabeth Stanton organized in Seneca Falls in 1848. This convention passed a Declaration of Sentiments, which criticized the American Declaration of Independence as it excluded women. The most prominent success achieved in this period was the US Congress passing the Nineteenth Amendment to the Constitution granting women the right to vote.

The 1960s saw the second wave of feminism, resulting from disappointment with the hitherto promotion of equality. The second-wave feminists claimed that the legal reforms did not provide women with the changes they expected. As feminists voiced the need to feminize the world, they struggled for social customs to change and gender stereotypes to be abandoned. They criticized the patriarchal model of American society, blaming this model for reducing the social role of women to that of a mother, wife and housewife. They pointed to patriarchal ideology, rather than nature, as the source of the inequality of sexes. The leading representatives of the second wave of feminism were Betty Friedan (who founded the National Organization for Women), Kate Millet (who wrote Sexual Politics), and Shulamith Firestone (the author of The Dialectic of Sex: The Case for Feminist Revolution).

The 1990s came to be called the third wave of feminism, characterized by multiple cultures, ethnic identities, races and religions, thereby becoming a heterogenic movement. The third-wave feminists, Rebecca Walker and Bell Hooks, represented groups of women who had formerly been denied the right to join the movement, for example due to racial discrimination. They believed that there was not one 'common interest of all women' but called for leaving no group out in the fight for the equality of women's rights. They asked that the process of women's emancipation that began with the first wave embrace and approve of the diversity of the multiethnic American society. 
